Converting California 

JAMES A. SANDOS

\section{Converting California}

INDIANS AND FRANCISCANS

IN THE MISSIONS

Yale University Press

New Haven \&

London 
Published with assistance from the Annie Burr Lewis Fund.

Copyright $\left({ }_{0} 2004\right.$ by Yale University. All rights reserved. This book may not be reproduced, in whole or in part, including illustrations, in any form (beyond that copying permitted by Sections I07 and I०8 of the U.S. Copyright Law and except by reviewers for the public press), without written permission from the publishers.

Set in Sabon type by Keystone Typesetting, Inc.

Printed in the United States of America by Sheridan Books.

LC Control Number: 2003070398

ISBN: 0-300-I0100-7

A catalogue record for this book is available from the British Library.

The paper in this book meets the guidelines for permanence and durability of the Committee on Production Guidelines for Book Longevity of the Council on Library Resources.

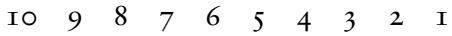


For Woodrow W. Borah and Sherburne F. Cook 
